Article

\title{
The Improvement Effects of Different Treatment Methods of Soil Wastewater Washing on Environmental Pollution
}

\author{
Linjie Zhan ${ }^{1}$ and Minxian Chen ${ }^{2, *}$ \\ 1 Faculty of Sciences, University of Macau, Taipa 999078, Macau, China; mb85223@connect.umac.mo \\ 2 School of Economics and Trade, Henan University of Technology, Zhengzhou 450001, China \\ * Correspondence: 201993503@stu.haut.edu.cn
}

Received: 13 July 2020; Accepted: 13 August 2020; Published: 19 August 2020

\begin{abstract}
This paper focus on how to treat the wastewater after soil washing since water pollution is a severe threat to the water security of China. $\mathrm{Ca}(\mathrm{OH})_{2}$ and two kinds of biochars (biochar and $\mathrm{ZnCl}_{2}$ modified biochar) were tested to treat the waste $\mathrm{FeCl}_{3}$ washing effluent. Two kinds of biochars (biochar and $\mathrm{ZnCl}_{2}$-modified biochar) were prepared from maize straws. Soil samples were collected near a smelter for adsorption experiments. ICP-OES was used to determine the concentration of metal ions in the samples, as well as calculating their adsorption capacity and removal rate. As to $\mathrm{Ca}(\mathrm{OH})_{2}$ treatment, the maximum removal rates of $\mathrm{Cd}, \mathrm{Pb}, \mathrm{Cu}$, and $\mathrm{Zn}$ could exceed $99 \%$, and the concentrations of $\mathrm{Cd}, \mathrm{Pb}, \mathrm{Cu}$, and $\mathrm{Zn}$ in solution could reduce to $0.08,0.018,0.15,0.44 \mathrm{mg} / \mathrm{dm}^{3}$, respectively. However, both of the two biochars had relatively low removal rates compared with $\mathrm{Ca}(\mathrm{OH})_{2}$ treatment. The wastewater shows significantly lower environmental implications after the two treatments, and the lime precipitation method has better effects than biochar adsorption. The activated carbon adsorption method discussed can significantly improve the environmental pollution caused by soil washing wastewater, which is suitable for environmental treatment projects.
\end{abstract}

Keywords: soil washing; wastewater treatment; heavy metal contamination; environmental implications; biochar

\section{Introduction}

Soil heavy metal pollution has been a severe problem, along with economic growth and rapid industrialization. According to a report by the Chinese government made in 2014, about $13 \%$ of farmland soils were polluted by heavy metals metalloids [1] in the soil survey. Heavy metals in soil can pose an enormous threat to the environment and human health, as their ability in poisoning plants and bioaccumulation [2]. Therefore, a large body of research in the remediation of heavy metal polluted soil has been conducted. The physical repair technology, chemical repair technology, biological repair technology, and joint repair technology are roughly summarized [3-6]. Soil washing was one of the most effective means among the different treatments of the heavy metal polluted soil. $\mathrm{FeCl}_{3}$ is a popular soil washing leachate [7], and it has already been applied in some countries to remediate soil contaminated by certain heavy metals, such as $\mathrm{Cd}$ and $\mathrm{Pb}[8,9]$.

Though soil washing can remove heavy metals in soil with high efficiency, the waste soil washing effluents would be a new hazardous to the environment, as the washing effluents contain high amounts of heavy metals after washing. Soil washing can generate a great deal of wastewater $[10,11]$. How to handle the wastewater is a severe problem when using soil washing to remediate heavy metal polluted soils. Conventional methods to treat soil washing leachate are electrochemical treatment [12], chemical precipitation [11], adsorption by biochar (BC), and photocatalytic degradation [13]. However, 
treatments, like electrochemical and photocatalytic degradation, usually need complicated devices or costly material. Moreover, the polluted soils are usually located in countries or suburbs, far away from sewage treatment plants, which means the washing effluents must be treated on-site and inexpensively with simple equipment. Therefore, chemical precipitation and adsorption progress are more available in treating waste soil washing effluents.

During the process of chemical precipitation, the chemical reagents could form hard soluble complexes with heavy metal ions; thus, the complexes precipitates can be separated from the water by precipitation or filtration, and the treated water can be discharged or reused [14]. Traditional chemical precipitation, such as hydroxide precipitation, sulfide precipitation, and ferrite precipitation, are widely used in industry [15]. As to hydroxide precipitation, alkaline materials are added to control the $\mathrm{pH}$ of the solution, and the undissolved hydroxide precipitation was generated to be separated from the water [16]. Lime is most commonly used to treat the sewage contained with heavy metal ions for its advantages of convenience and economic operation [17]. Many studies [8,17,18] have found that lime had an excellent removal capacity for metal ions.

The pyrolysis of biomass materials produces BC under low temperatures and limited oxygen conditions. With ample surface area and strong adsorption [14], BC adsorbing has also received significant attention, and is popularly used during the treatment of industrial wastewater [19]. A previous study found that maize BC has a better immobilizing effect than corn straw, wheat straw, or cotton straw during the remediation of $\mathrm{Pb}$ and $\mathrm{Cd}$ in soil [20-22]. Experiments have proved that $\mathrm{ZnCl}_{2}$ modified BC had a good effect in increasing low-cost carbon surface area [23,24].

Soil washing to remove heavy metals in soil has been reported by numerous researchers $[8,10,25]$. However, research about the treatment of waste washing effluents are relatively rare. Therefore, this article focuses on (1) adding $\mathrm{Ca}(\mathrm{OH})_{2}$ to treat waste $\mathrm{FeCl}_{3}$ washing effluent; (2) using $\mathrm{BC}$ and $\mathrm{ZnCl}_{2}$ modified $\mathrm{BC}$ to treat the waste effluent; (3) investigating the applicability of the two treatments and to compare them based on their efficiency. Two kinds of BCs were prepared, and an electron microscope observed their microstructure. Soil samples near the smelter were collected, and the values of BCs for heavy metal adsorption in wastewater and environmental pollution control were explored through experiments.

\section{Materials and Methods}

\subsection{BC Sample Preparation and Characterization}

Two kinds of $\mathrm{BCs}$ ( $\mathrm{BC}$ and $\mathrm{ZnCl}_{2}$ modified $\mathrm{BC}$ ) were prepared in the experiment, and they were all made by maize straws from Xinyang city in China. After washed with deionized water, we dried them at $100{ }^{\circ} \mathrm{C}$ for $10 \mathrm{~h}$, then smashed and sieved them through a $1 \mathrm{~mm}$ sieve. BC was pyrolyzed in nitrogen at the temperature of $450{ }^{\circ} \mathrm{C}$ for $2 \mathrm{~h}$ in a ceramic pot. For the preparation of $\mathrm{ZnCl}_{2}$-modified $\mathrm{BC}(\mathrm{ZnBC})$, the maize straw was immersed in $\mathrm{ZnCl}_{2} 1 \mathrm{M}$ solution for $24 \mathrm{~h}$ at room temperature, using a proportion of $\mathrm{ZnCl}_{2}$ respect maize straw at a mass ratio equal to 1 [26]. Then, the modified $\mathrm{BC}$ was pyrolyzed in a ceramic tank filled with nitrogen at $450{ }^{\circ} \mathrm{C}$ for $2 \mathrm{~h}$. The obtained materials were dried at $100{ }^{\circ} \mathrm{C}$ for $10 \mathrm{~h}$ and finally pyrolyzed with the same condition of BC. Both of the two BC samples were washed with deionized thoroughly until the $\mathrm{pH}$ of the supernatant was around 7. Next, the soil samples were dried and sieved through a $100 \mu \mathrm{m}$ sieve. Then, the obtained BCs were added to the soil samples for experimentation.

The characteristics [26] of BC and ZnBC were tested as follows: an automatic Micromeritics measured pore characteristics ASAP2460 volumetric sorption analyzer (Micromeritics Instrument Corp., Norcross, GA, USA), and the microstructure and morphology were acquired by scanning-electron-microscopy (SEM) through Nova Nano SEM 230 (USA). 


\subsection{Soil Characteristics and the Soil Washing Effluents}

The soil sample was collected near a smelter in Zhuzhou city, China, which had high contamination levels of $\mathrm{Cd}, \mathrm{Pb}, \mathrm{Cu}$, and $\mathrm{Zn}$. After collection, the soil was air-dried at room temperature and passed through a $2 \mathrm{~mm}$ sieve. We tested soil $\mathrm{pH}$ with a liquid-solid ratio of 1:2.5 [27], soil organic matter (SOM) after $\mathrm{K}_{2} \mathrm{Cr}_{2} \mathrm{O}_{7}$ digestion [28], cation exchange capacity (CEC) through $\mathrm{BaCl}_{2}$ displaced [29] soil texture [30] (Ball, 1964), and total soil $\mathrm{Pb}, \mathrm{Cu}, \mathrm{Zn}$, and $\mathrm{Cd}$ contents by inductively coupled plasma-optical emission spectrometry (ICP-OES) after $\mathrm{HNO}_{3}-\mathrm{HClO}_{4}-\mathrm{HF}$ digestion [31]. The main physicochemical characteristics of the soil are shown in Table 1 (USDA).

Table 1. The main characteristics of the soil sample.

\begin{tabular}{cc}
\hline Variables/Properties and Units & Value \\
\hline Clay $(\%)$ & $32.81 \pm 0.04$ \\
Silt $(\%)$ & $43.27 \pm 3.43$ \\
Sand $(\%)$ & $23.92 \pm 3.48$ \\
$\mathrm{pH}$ & $5.22 \pm 0.03$ \\
$\mathrm{SOM}(\%)$ & $38.43 \pm 0.59$ \\
$\mathrm{CEC}(\mathrm{cmol} / \mathrm{kg})$ & $20.50 \pm 1.30$ \\
$\mathrm{Fe}(\mathrm{g} / \mathrm{kg})$ & $32.13 \pm 3.18$ \\
$\mathrm{Cd}(\mathrm{mg} / \mathrm{kg})$ & $16.83 \pm 0.22$ \\
$\mathrm{~Pb}(\mathrm{mg} / \mathrm{kg})$ & $465.28 \pm 2.36$ \\
$\mathrm{Cu}(\mathrm{mg} / \mathrm{kg})$ & $182.43 \pm 2.25$ \\
$\mathrm{Zn}(\mathrm{mg} / \mathrm{kg})$ & $1178.35 \pm 1.58$ \\
\hline
\end{tabular}

We placed six hundred grams of the soil sample to $2 \mathrm{~L}$ Pyrex beaker, then filled with $900 \mathrm{~cm}^{3}$ of $0.1 \mathrm{M} \mathrm{FeCl}_{3}$, so that the liquid to solid ratio was about 1:1.5 [32]. We stirred the mixture by a magnetic stir rod at a fast speed. After stirring for $1 \mathrm{~h}$ at room temperature, we centrifuged the soil suspensions by $100 \mathrm{~cm}^{3}$ plastic bottles at $4000 \mathrm{rpm}$ for $10 \mathrm{~min}$. The supernatant was then prepared for the next experiment after being filtered through a $0.45 \mu \mathrm{m}$ membrane filter. The heavy metals concentrations $(\mathrm{Cd}, \mathrm{Pb}, \mathrm{Cu}$, and $\mathrm{Zn})$ in the waste washing water were analyzed by ICP-OES. The $\mathrm{pH}$ value of wastewater was 3.42, and the water quality monitoring results were shown in Table 2.

Table 2. Monitoring results of heavy metal contents in wastewater.

\begin{tabular}{cc}
\hline Metal Elements & Concentration $\left(\mathbf{m g} \cdot \mathbf{L}^{-\mathbf{1}}\right)$ \\
\hline $\mathrm{Fe}$ & 27.1 \\
$\mathrm{Mg}$ & 122.6 \\
$\mathrm{Mn}$ & 3.8 \\
$\mathrm{Cu}$ & 0.006 \\
$\mathrm{Zn}$ & 212.5 \\
$\mathrm{~Pb}$ & 0.3 \\
$\mathrm{Cd}$ & 84.4 \\
\hline
\end{tabular}

\subsection{Heavy Metals Removal from the Washing Wastewater by $\mathrm{Ca}(\mathrm{OH})_{2}$ Addition}

Placed $40 \mathrm{~cm}^{3}$ of the waste soil washing effluent (in Section 2.3.) in an Erlenmeyer flask, after adding a series concentrations of $\mathrm{Ca}(\mathrm{OH})_{2}$ powder $(0,0.8,1.6,2.4,3.2,4.0,4.8,6.4,8.0,12.0$, and $20.0 \mathrm{mg} / \mathrm{dm}^{3}$ ), we equilibrated them on a shaker at the speed of $60 \mathrm{rpm}$ for $1 \mathrm{~h}$ with a temperature of $25{ }^{\circ} \mathrm{C}$ [33]. We filtered the supernatants via a $0.45 \mu \mathrm{m}$ membrane filter to measure the metals concentrations by ICP-OES. The $\mathrm{pH}$ values were acquired by $\mathrm{HI} 3221 \mathrm{pH}$ meter. 


\subsection{Adsorption of Heavy Metals by BCs in the Wastewater}

To achieved better experiment conditions, we used $0.2 \mathrm{~g} \mathrm{BC}$ and $\mathrm{ZnBC}$ to absorb $\mathrm{Cu}^{2+}$ with a volume of $100 \mathrm{~cm}^{3}$ at a concentration of $100 \mathrm{mg} / \mathrm{L}$, with vibration time of $4 \mathrm{~h}$. Both BC and $\mathrm{ZnBC}$ reached their saturated adsorption after the 6 th $\mathrm{h}$.

To measure the adsorption abilities of $\mathrm{BC}$ and $\mathrm{ZnBC}$, we added them at a concentration of $0,0.01$, $0.02,0.04,0.06,0.08,0.1,0.2,0.5$, and $1.0 \mathrm{~g}$ to $40 \mathrm{~cm}^{3}$ wastewater in Erlenmeyer flasks. After shaking the mixture at $60 \mathrm{rpm}$ at $25^{\circ} \mathrm{C}$ for $6 \mathrm{~h}$, we tested the metal concentrations of the suspensions as above.

All experiments were performed in triplicates. Means and standard deviations were calculated with Microsoft Excel.

\section{Results and Discussion}

\subsection{BC Characterization}

\subsubsection{SEM Analysis}

The SEM images of BC and ZnBC are shown in Figure 1. The dark zones and light zones, are each referred to carbon structure and metal oxides [26]. As shown, BC had an ordered structure, contained porous morphology and some small particles on its surface [26]. After the modification by $\mathrm{ZnCl}_{2}$, the original structure was broken, several metal oxides appeared on the carbon sheet. As a consequence, the surface area was increased compared to $\mathrm{BC}$ carbon.

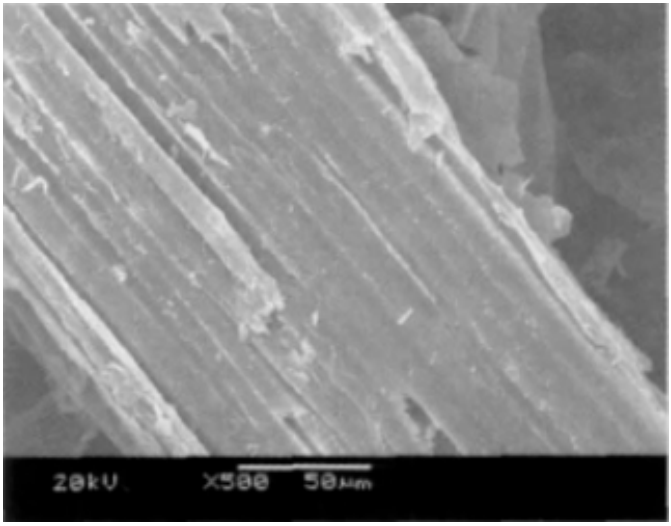

(a)

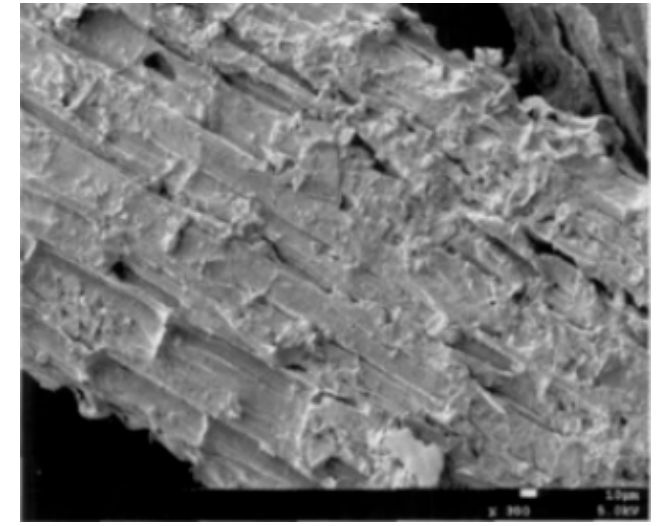

(b)

Figure 1. SEM images of BC and ZnBC: (a) BC, (b) ZnBC.

\subsubsection{BET Analysis}

The Brunauer-Emmett-Teller (BET) surface area and pore characters of the BC and ZnBC are listed in Table 3. After $\mathrm{ZnCl}_{2}$ modified, BET surface area and total pore volume of the BC increased significantly, whereas average pore diameter showed minimal decrease: the BET surface area of $\mathrm{ZnBC}$ was increased from 59.21 to $780.23 \mathrm{~m}^{2} / \mathrm{g}$, thirteen folds more than $\mathrm{BC}$; the total pore volume of $\mathrm{ZnBC}$ was increased by $350 \%$ compared to $\mathrm{BC}$. A previous study [24] also found that $\mathrm{ZnCl}_{2}$ modified carbon could increase $\mathrm{C}$ content in the proportion of the $\mathrm{BC}$. As a consequence, the BET surface and the total pore volume of the $\mathrm{BC}$ were increased after activated by $\mathrm{ZnCl}_{2}$. However, $\mathrm{ZnCl}_{2}$ might promote the polymerization of tar-forming compounds or the retention of the tar-forming compounds in the pore structure, which would decrease the average pore diameter as a consequence [34]. 
Table 3. The BET surface area and pore characters of the samples.

\begin{tabular}{cccc}
\hline Sample. & $\begin{array}{c}\text { BET Surface Area } \\
\left(\mathbf{m}^{\mathbf{2}} \mathbf{g}\right)\end{array}$ & $\begin{array}{c}\text { Total Pore Volume } \\
\left(\mathbf{c m}^{\mathbf{3}} \mathbf{/ g}\right)\end{array}$ & $\begin{array}{c}\text { Average Pore Diameter } \\
(\mathbf{n m})\end{array}$ \\
\hline $\mathrm{BC}$ & 59.21 & 0.17 & 2.60 \\
$\mathrm{ZnBC}$ & 780.23 & 0.59 & 2.57 \\
\hline
\end{tabular}

\subsection{Heavy Metals Removal by $\mathrm{Ca}(\mathrm{OH})_{2}$ Addition}

The influence of lime dosage on the heavy metal removal rates is shown in Figure 2. Since $\mathrm{FeCl}_{3}$ is a weakly alkaline salt, it could generate a large number of $\mathrm{H}^{+}$in the washing solution. When $\mathrm{Ca}(\mathrm{OH})_{2}$ was put into the wastewater, $\mathrm{OH}^{-}$would neutralize the free $\mathrm{H}^{+}$in the water firstly. After that, the $\mathrm{pH}$ of the waste would increase along with the addition of $\mathrm{Ca}(\mathrm{OH})_{2}$. The solution $\mathrm{pH}$ had a significant effect on the solubility of heavy metals. According to the research of [35], the hydroxide of metals would not be formed until the solution $\mathrm{pH}$ reached the "adsorption edge." Generally, the $\mathrm{pH}$ of the solution controls the degree of dissociation of acidic or basic compounds. When the $\mathrm{pH}$ reaches a specific range, these compounds will dissociate and thereby affect the adsorption of them. Makino et al. (2016) [11] found that the solubility product constant $(\mathrm{Ksp})$ of $\mathrm{Cd}, \mathrm{Pb}, \mathrm{Cu}$, and $\mathrm{Zn}$ were $2.8 \times 10^{-14}, 1.1 \times 10^{-20}, 1.9$ $\times 10^{-20}$, and $4 \times 10^{-17}$, respectively. The maximum removal rates of $\mathrm{Cd}, \mathrm{Pb}, \mathrm{Cu}$, and $\mathrm{Zn}$ could exceed $99 \%$ when the $\mathrm{pH}$ was around 7 , and the concentrations of $\mathrm{Cd}, \mathrm{Pb}, \mathrm{Cu}$, and $\mathrm{Zn}$ in solution could reduce to $0.08,0.018,0.15,0.44 \mathrm{mg} / \mathrm{dm}^{3}$, respectively.

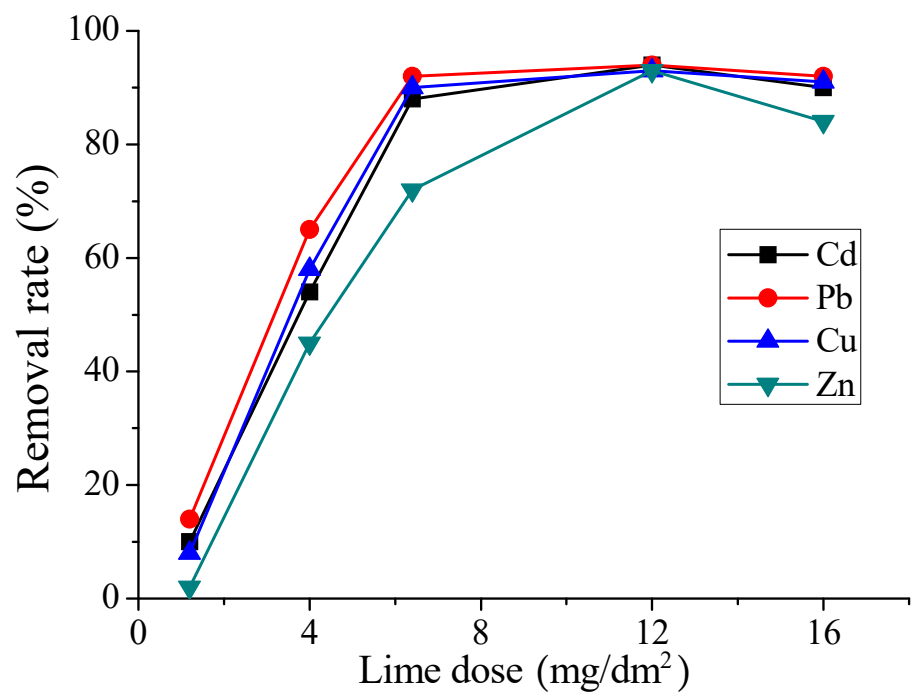

Figure 2. Influence of lime dosage on the heavy metal removal rates.

$\mathrm{OH}^{-}$will react with the amino groups on the surface of the $\mathrm{BC}$ through hydrogen bonding; thus, the surface of the amino-modified $\mathrm{BC}$ presents negative charges. The effect of positive and negative charges is beneficial to the adsorption of $\mathrm{Pb}^{2+}$. Due to the difference in the $\mathrm{pH}$ values of the aqueous solution, the existence of $\mathrm{Pb}$ and $\mathrm{Cd}$ ions are also different. If the $\mathrm{pH}$ value is less than 6 , the chemical ions will exist in the form of free $\mathrm{Pb}^{2+}$; if the $\mathrm{pH}$ value is greater than 6 , the hydroxyl complex ions of $\mathrm{Pb}$ will be gradually generated and begin to precipitate. For $\mathrm{Cd}$ ions, if the $\mathrm{pH}$ value of the solution is less than 8 , it will exist in the form of $\mathrm{Cd}^{2+}$ and a small amount of $\mathrm{CdOH}^{+}$ions; if the $\mathrm{pH}$ value is greater than $8, \mathrm{Cd}$ precipitation will gradually occur.

\subsection{BC Sorption of Heavy Metals}

Removal rates of heavy metals by $\mathrm{BC}$ and $\mathrm{ZnBC}$ in waste soil washing effluent were shown in Figure 3. After soil washing, the $\mathrm{pH}$ of the waste effluent was 2.41. $\mathrm{ZnBC}$ had better effects on the absorption of $\mathrm{Cd}, \mathrm{Pb}, \mathrm{Cu}$, and $\mathrm{Zn}$ than $\mathrm{BC}$. The removal rate of $\mathrm{Cd}, \mathrm{Pb}, \mathrm{Cu}$, and $\mathrm{Zn}$ when treated 
with BC were 40.01\%, 61.23\%, 48.56\%, and 33.27\%, respectively. Compared with BC, Zn BC had much better adsorption capacity of metal ions in the wastewater, and the removal rates of $\mathrm{Cd}, \mathrm{Pb}, \mathrm{Cu}$, and Zn were 93.18\%, 99.23\%, 95.44\%, and 90.67\%, respectively. According to previous research [36,37], sorption of the metal ion by BC is mainly influenced by BC surface chemistry and its surface area or by precipitation reactions. Therefore, pyrolytic temperature [38], surface chemistry [39] modification, and the solution $\mathrm{pH}$ [40] would exert a significant impact on the adsorption performance of BC. For example, some BCs had the maximum adsorption of metal ions when the solution $\mathrm{pH}$ value was around 5 [40-42]. In consequence, the high specific surface area of ZnBC was probably an important reason for its higher removal capacity, compared to BC. According to Section 3.1, the BET surface area of $\mathrm{ZnBC}$ is thirteen times larger than $\mathrm{BC}$, which means there would be more adsorption sites available for the adsorption of heavy metals $[43,44]$. On the other side, the main existing form of $\mathrm{Zn}$ was $\mathrm{Zn}-\mathrm{OH}$ on the surface of $\mathrm{ZnBC}$ after $\mathrm{ZnCl}_{2}$ activated [24]. As a consequence, ions exchange could happen between $\mathrm{Zn}-\mathrm{OH}$ and metal ions $(\mathrm{Cd}, \mathrm{Pb}$, and $\mathrm{Cu})$. The ionic radius of $\mathrm{Cd}, \mathrm{Pb}, \mathrm{Cu}$, and $\mathrm{Zn}$ were 0.97 , $1.21,0.70$, and $0.74 \mathrm{~nm}$ [45], respectively; the average pore diameter of BC and $\mathrm{ZnBC}$ were 2.60 and $2.57 \mathrm{~nm}$. So, the metal ions could fill in the micropores of both $\mathrm{BC}$. Therefore, $\mathrm{ZnCl}_{2}$ modified BC possessed the practical value for removing metal ions in the waste washing effluent.
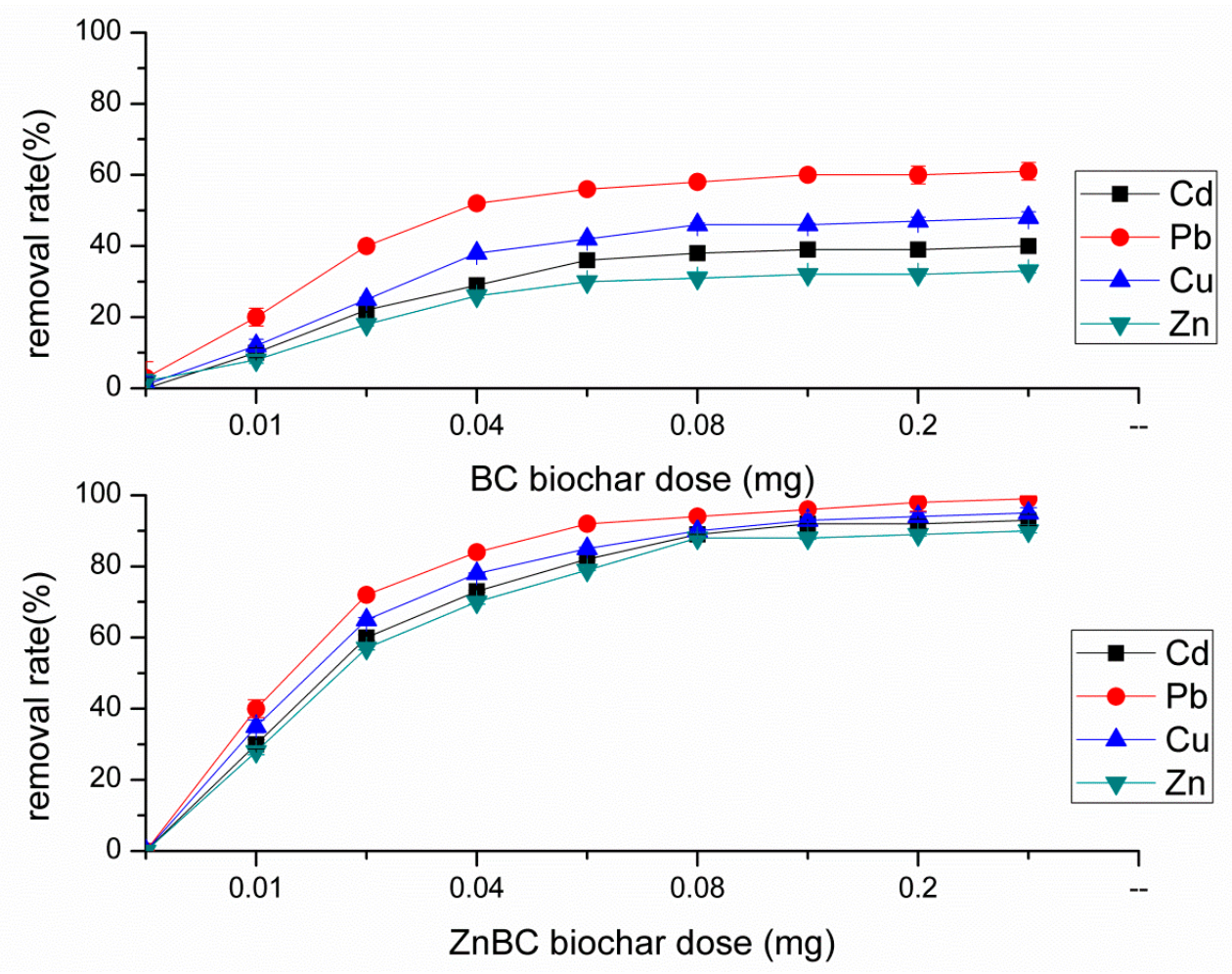

Figure 3. Removal rates of heavy metals by BC and ZnBC in waste soil washing effluent.

The equilibrium adsorption quantity qe of $\mathrm{ZnBC}$ adsorbing $\mathrm{Cd}^{2+}$ and $\mathrm{Pb}^{2+}$ with the equilibrium concentration $\mathrm{Ce}$ in the solution after adsorption equilibrium was plotted; the adsorption isotherms of $\mathrm{ZnBC}$ adsorbing $\mathrm{Cd}^{2+}$ and $\mathrm{Pb}^{2+}$ at different temperatures were obtained, as shown in Figure 4. Under the experimental conditions, when the equilibrium concentration was lower, the specific adsorption capacity of $\mathrm{ZnBC}$ for $\mathrm{Cd}^{2+}$ and $\mathrm{Pb}^{2+}$ increased sharply with the increase in the solution concentration, showing that the adsorbent had high adsorption capacity even at low concentrations. The specific adsorption capacity of the adsorbent for $\mathrm{Cd}^{2+}$ and $\mathrm{Pb}^{2+}$ generally increased with the increase in temperature, indicating that heating was beneficial to adsorption. Generally, increasing the temperature will increase the diffusion rate of adsorbate molecules in the outer boundary layer of the adsorbent. Second, temperature changes may affect the equilibrium adsorption capacity of the adsorbent. Figure 4 
illustrated that the amount of adsorption increased with an increase in temperature. This change indicated that the reaction was endothermic.

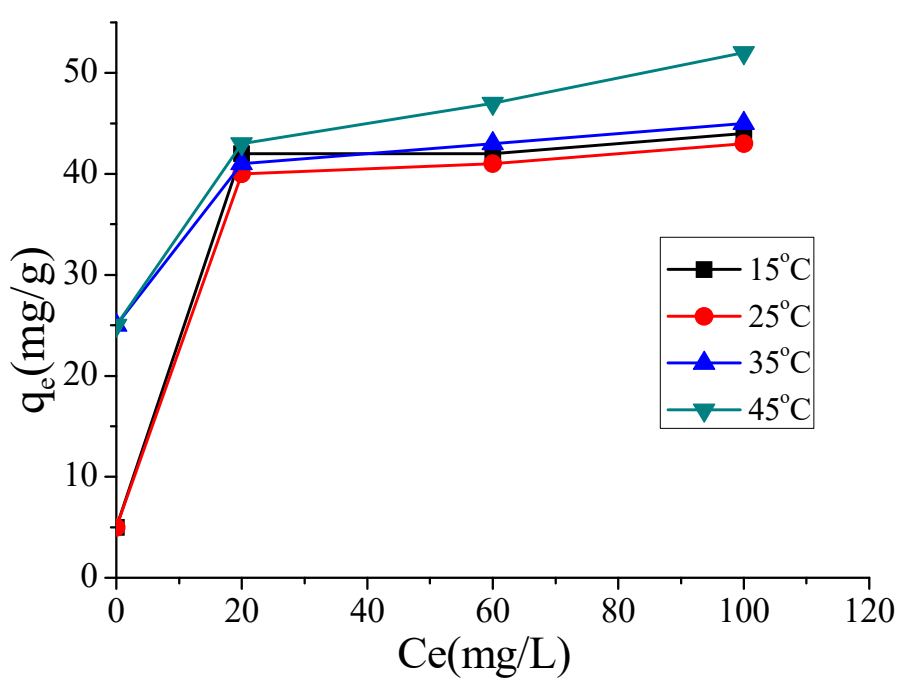

(a) The adsorption isotherm of $\mathrm{ZnBC}$ to $\mathrm{Pb}^{2+}$.

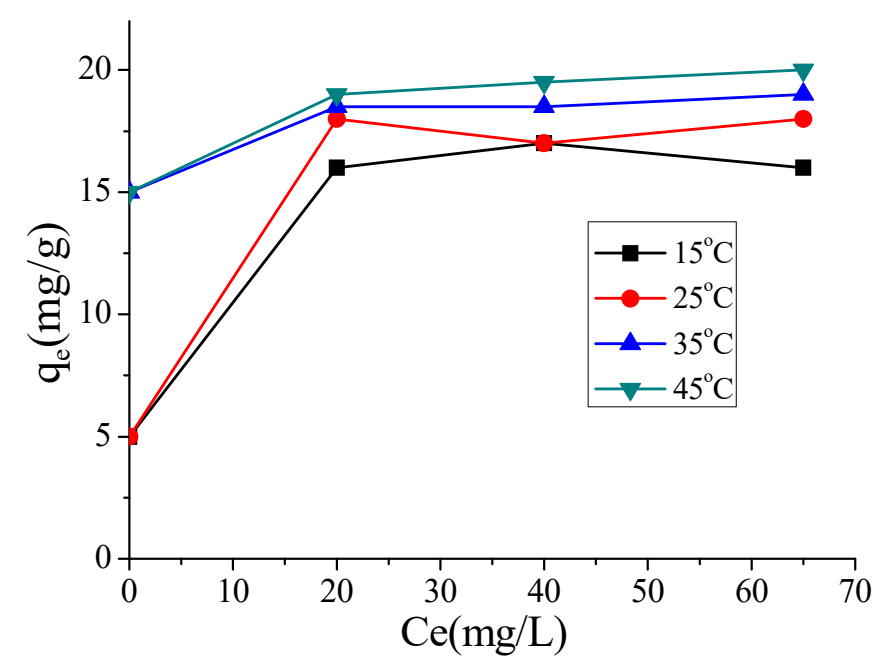

(b) The adsorption isotherm of $\mathrm{ZnBC}$ to $\mathrm{Cd}^{2+}$.

Figure 4. Adsorption isotherms of $\mathrm{ZnBC}$ to $\mathrm{Cd}^{2+}$ and $\mathrm{Pb}^{2+}$ at different temperatures. (a) shows that under the same test conditions, the adsorption capacity will increase with the increase of temperature. (b) shows the increase of temperature will increase the diffusion rate of adsorbate molecules in the external boundary layer of adsorbent.

\subsection{Comparison of $\mathrm{Ca}(\mathrm{OH})_{2}$ and $\mathrm{BC}$ Treatment}

Previous researchers (Chen et al., 2009 [17]; Chen et al., 2011 [40]; Makino et al., 2016 [11]) found that the formation of hydroxide metals or other complexes with metals had a significant influence on the removal of heavy metals, as they could precipitate from the water. Furthermore, our experiments indicated $\mathrm{Ca}(\mathrm{OH})_{2}$ had a better effect in increasing solution $\mathrm{pH}$ than $\mathrm{BCs}(\mathrm{BC}$ and $\mathrm{ZnBC}$ ), which could be the main reason that $\mathrm{Ca}(\mathrm{OH})_{2}$ had better removal rates of $\mathrm{Cd}, \mathrm{Pb}, \mathrm{Cu}$, and $\mathrm{Zn}$ than above $\mathrm{BCs}$ during the treatment of waste $\mathrm{FeCl}_{3}$ washing effluent. Though the solution $\mathrm{pH}$ was around 9 after 
$\mathrm{Ca}(\mathrm{OH})_{2}$ treatment, the cleaned wastewater could help to neutralize the soil acidity caused by $\mathrm{FeCl}_{3}$ washing [8], but the concentration of $\mathrm{Cd}, \mathrm{Pb}, \mathrm{Cu}$, and $\mathrm{Zn}$ were $0.08,0.018,0.15$, and $0.44 \mathrm{mg} / \mathrm{dm}^{3}$, which exceed the values of Chinese effluent standards [46]. Therefore, the cleaned waste effluent could not be discharged into the soil or rivers nearby directly. Further treatments, such as the adsorption by activated carbon [47] and membrane filtration treatment $[48,49]$ were needed to meet the effluent standards. Furthermore, the cleaned wastewater could not be reused to pair the $\mathrm{FeCl}_{3}$ soil washing solution, unless there was enough $\mathrm{HCl}$ or other acid to neutralize the excess $\mathrm{OH}^{-}$in the water. Some researchers found that the activated carbon had an excellent removal capacity of metal ions, some of them can remove nearly $100 \%$ metal ions in solution [48,50]. However, both BCs in our experiment had low removal rates of $\mathrm{Cd}, \mathrm{Pb}, \mathrm{Cu}$, and $\mathrm{Zn}$. Previous studies (Chen et al., 2013 [51]; Xu et al., 2020 [52]) found $\mathrm{BC}$ showed preferable adsorption capacity when the $\mathrm{pH}$ value was greater than 5 , while the $\mathrm{pH}$ of the waste effluent was 2.41, which could be the main reason for the low performance of BC and ZnBC. As maize straws contain multiple complex chemical compositions, including cellulose, hemicellulose, lignin, and soluble sugar. These compositions can bind with heavy metal ion through hydrogen bonds or ion exchange, which could be influenced by $\mathrm{pH}$. Therefore, $\mathrm{BC}$ s were in-suitable to treat waste $\mathrm{FeCl}_{3}$ washing effluent directly. Since solution $\mathrm{pH}$ had a significant influence on the removal capacity of active carbon [40], the combination of $\mathrm{Ca}(\mathrm{OH})_{2}$ and $\mathrm{BC}$ to treat waste effluent might achieve a better effect than just $\mathrm{Ca}(\mathrm{OH})_{2}$ or $\mathrm{BC}$ treatment alone.

\section{Discussion}

Globally, the research on BC focuses on its applications in agricultural soil. However, reports on the chemical modification of $\mathrm{BC}$, as well as the application of modified $\mathrm{BC}$ in treating heavy metals in wastewater, are rare. Therefore, a theoretical basis will be provided for the application of $\mathrm{BC}$ from the perspective of waste recycling and environmental remediation. Based on the application of $\mathrm{BC}$ in wastewater treatment, first, maize straws, a universal intercultural solid waste, were selected as the biomass raw materials to prepare and modify the BC adsorbent. Then, the adsorbent's adsorption performance to heavy metals was explored.

The prepared adsorbent $\mathrm{ZnBC}$ could adsorb different kinds of metal ions and completely treat low-concentration heavy metal-polluted wastewater. Since the magnetic BC adsorbs metal ions due to surface adsorption and surface activity, the active site on the surface is easy to be combined with positively charged metal ions [53]. Besides, the characterization analysis showed that magnetic BC had some unsaturated carbon bonds, carboxyl groups, hydroxyl groups, and other groups that were easily substituted with metal ions; they could bind to metal ions in the solution to remove the heavy metal pollutants in industrial wastewater. The experimental results showed that the hydroxide and sulfide precipitation method had a more significant impact on $\mathrm{Zn}^{2+}$ and $\mathrm{Cd}^{2+}$ in wastewater. Marshall et al. treated soybean and cotton husks with $\mathrm{NaOH}$ to improve their ability to adsorb $\mathrm{Zn}^{2+}$, which was consistent with the results of this experiment $[54,55]$. In addition, a simple analysis of the possibility of the $\mathrm{BC}$ adsorption mechanism was carried out. The removal mechanism of heavy metals in aqueous solution by $\mathrm{BC}$ was more likely to be based on the co-precipitation of functional groups on the surface of BC.

\section{Conclusions}

Soil heavy metal pollution is a severe problem, along with economic growth and rapid industrialization. The ongoing food safety risk events push the security problems of agricultural products to an important issue and caused widespread social panic. Soil washing is an effective remedy to remove heavy metals, which is widely approved by the international community. However, how to treat the wastewater after soil washing is a significant social problem. In this paper, two simplified, highly efficient, cost-effective on-site methods- $\mathrm{BC}$ adsorption and lime precipitation method-had been investigated to treat washing wastewater containing $\mathrm{Cd}, \mathrm{Cu}, \mathrm{Pb}$, and $\mathrm{Zn}$. The washing wastewater was obtained from on-site soil washing with $\mathrm{FeCl}_{3}$. The experiment revealed that these treatments 
could effectively remove all of the metals in the pretreated water, and the lime precipitation method has better effects than $\mathrm{BC}$ adsorption. During precipitation of metals ions with $\mathrm{Ca}(\mathrm{OH})_{2}$, the maximum removal rates of $\mathrm{Cd}, \mathrm{Pb}, \mathrm{Cu}$, and $\mathrm{Zn}$ could exceed $99 \%$, and the corresponding concentrations of $\mathrm{Cd}$, $\mathrm{Pb}, \mathrm{Cu}$, and $\mathrm{Zn}$ in solution could reduce to $0.08,0.018,0.15$, and $0.44 \mathrm{mg} / \mathrm{dm}^{3}$, respectively.

Because the actual environmental factors are more complicated, after some time (maybe several years, decades, or hundreds of years), various physical and chemical changes and biological reactions may exist. BC is common in water or soils, while the existing problems of aging and deterioration have to be considered. Therefore, limitations exist in the experimental process. In the future, it is necessary to carry out long-term tracking and monitoring of amino-modified $\mathrm{BC}$ to ensure its stable, functional applicability.

Author Contributions: Conceptualization, L.Z. and M.C.; writing-original draft preparation, L.Z.; writing-review and editing, M.C.; All authors have read and agreed to the published version of the manuscript.

Funding: This research received no external funding.

Acknowledgments: The authors acknowledge the help from the researchers in University of Macau and Henan University of Technology.

Conflicts of Interest: The authors declare no conflict of interest.

\section{References}

1. Zhao, F.-J.; Ma, Y.; Zhu, Y.-G.; Tang, Z.; McGrath, S.P. Soil Contamination in China: Current Status and Mitigation Strategies. Environ. Sci. Technol. 2015, 49, 750-759. [CrossRef]

2. Viard, B.; Pihan, F.; Promeyrat, S.; Pihan, J.-C. Integrated assessment of heavy metal ( $\mathrm{Pb}, \mathrm{Zn}, \mathrm{Cd}$ ) highway pollution: Bioaccumulation in soil, Graminaceae and land snails. Chemosphere 2004, 55, 1349-1359. [CrossRef]

3. Beiyuan, J.; Lau, A.Y.; Tsang, D.C.W.; Zhang, W.; Kao, C.-M.; Baek, K.; Ok, Y.S.; Li, X. Chelant-enhanced washing of CCA-contaminated soil: Coupled with selective dissolution or soil stabilization. Sci. Total. Environ. 2018, 612, 1463-1472. [CrossRef] [PubMed]

4. Bolan, N.; Kunhikrishnan, A.; Thangarajan, R.; Kumpiene, J.; Park, J.; Makino, T.; Kirkham, M.B.; Scheckel, K.G. Remediation of heavy metal(loid)s contaminated soils-To mobilize or to immobilize. J. Hazard. Mater. 2014, 266, 141-166. [CrossRef] [PubMed]

5. Jiang, J.; Wu, L.; Li, N.; Luo, Y.; Liu, L.; Zhao, Q.; Zhang, L.; Christie, P. Effects of multiple heavy metal contamination and repeated phytoextraction by Sedum plumbizincicola on soil microbial properties. Eur. J. Soil Biol. 2010, 46, 18-26. [CrossRef]

6. Sun, Y.; Xu, Y.; Xu, Y.; Wang, L.; Liang, X.; Li, Y. Reliability and stability of immobilization remediation of Cd polluted soils using sepiolite under pot and field trials. Environ. Pollut. 2016, 208, 739-746. [CrossRef] [PubMed]

7. Makino, T.; Sugahara, K.; Sakurai, Y.; Takano, H.; Kamiya, T.; Sasaki, K.; Itou, T.; Sekiya, N. Remediation of cadmium contamination in paddy soils by washing with chemicals: Selection of washing chemicals. Environ. Pollut. 2006, 144, 2-10. [CrossRef]

8. Guo, X.; Wei, Z.; Wu, Q.; Li, C.; Qian, T.; Zheng, W. Effect of soil washing with only chelators or combining with ferric chloride on soil heavy metal removal and phytoavailability: Field experiments. Chemosphere 2016, 147, 412-419. [CrossRef]

9. Makino, T.; Takano, H.; Kamiya, T.; Itou, T.; Sekiya, N.; Inahara, M.; Sakurai, Y. Restoration of cadmium-contaminated paddy soils by washing with ferric chloride: Cd extraction mechanism and bench-scale verification. Chemosphere 2008, 70, 1035-1043. [CrossRef]

10. Dermont, G.; Bergeron, M.; Mercier, G.; Richer-LaFLèche, M. Soil washing for metal removal: A review of physical/chemical technologies and field applications. J. Hazard. Mater. 2008, 152, 1-31. [CrossRef]

11. Makino, T.; Maejima, Y.; Akahane, I.; Kamiya, T.; Takano, H.; Fujitomi, S.; Ibaraki, T.; Kunhikrishnan, A.; Bolan, N. A practical soil washing method for use in a Cd-contaminated paddy field, with simple on-site wastewater treatment. Geoderma 2016, 270, 3-9. [CrossRef] 
12. Ferraro, A.; Van Hullebusch, E.D.; Huguenot, D.; Fabbricino, M.; Esposito, G. Application of an electrochemical treatment for EDDS soil washing solution regeneration and reuse in a multi-step soil washing process: Case of a Cu contaminated soil. J. Environ. Manag. 2015, 163, 62-69. [CrossRef] [PubMed]

13. Satyro, S.; Race, M.; Di Natale, F.; Erto, A.; Guida, M.; Marotta, R. Simultaneous removal of heavy metals from field-polluted soils and treatment of soil washing effluents through combined adsorption and artificial sunlight-driven photocatalytic processes. Chem. Eng. J. 2016, 283, 1484-1493. [CrossRef]

14. Fu, F.; Wang, Q. Removal of heavy metal ions from wastewaters: A review. J. Environ. Manag. 2011, 92, 407-418. [CrossRef]

15. Yan, X.; Chen, M.; Chen, M.-Y. Coupling and Coordination Development of Australian Energy, Economy, and Ecological Environment Systems from 2007 to 2016. Sustainability 2019, 11, 6568. [CrossRef]

16. Huisman, J.L.; Schouten, G.; Schultz, C. Biologically produced sulphide for purification of process streams, effluent treatment and recovery of metals in the metal and mining industry. Hydrometall 2006, 83, 106-113. [CrossRef]

17. Chen, Q.; Luo, Z.; Hills, C.; Xue, G.; Tyrer, M. Precipitation of heavy metals from wastewater using simulated flue gas: Sequent additions of fly ash, lime and carbon dioxide. Water Res. 2009, 43, 2605-2614. [CrossRef]

18. Ghosh, P.; Samanta, A.N.; Ray, S. Reduction of COD and removal of Zn2+ from rayon industry wastewater by combined electro-Fenton treatment and chemical precipitation. Desalination 2011, 266, 213-217. [CrossRef]

19. Kadirvelu, K. Removal of heavy metals from industrial wastewaters by adsorption onto activated carbon prepared from an agricultural solid waste. Bioresour. Technol. 2001, 76, 63-65. [CrossRef]

20. An, M.; Dong, L.; Zhang, L.; Sun, C.-H.; Xia, P. Influence of different kinds of BC on Cd and Pb forms in soil. J. Agro. Environ. Sci. 2018, 37, 892-898.

21. Khorram, M.S.; Zheng, Y.; Lin, D.; Zhang, Q.; Fang, H.; Yuet, Y. Dissipation of fomesafen in BC-amended soil and its availability to corn (Zea mays L.) and earthworm (Eisenia fetida). J. Soils Sediments 2016, 16, 2439-2448. [CrossRef]

22. Shaheen, A.; Syed, T.A.B. Potential of sawdust and corn cobs derived BC to improve soil aggregate stability, water retention, and crop yield of degraded sandy loam soil. J. Plant Nutr. 2018, 41, 2673-2682. [CrossRef]

23. Boudrahem, F.; Soualah, A.; Aissani-Benissad, F. Pb(II) and Cd(II) Removal from Aqueous Solutions Using Activated Carbon Developed from Coffee Residue Activated with Phosphoric Acid and Zinc Chloride. J. Chem. Eng. Data 2011, 56, 1946-1955. [CrossRef]

24. Xia, D.; Tan, F.; Zhang, C.; Jiang, X.; Chen, Z.; Li, H.; Zhenga, Y.; Li, Q.; Wang, Y. ZnCl2-activated BC from biogas residue facilitates aqueous As(III) removal. Appl. Surf. Sci. 2016, 377, 361-369. [CrossRef]

25. Wei, M.; Chen, J.; Wang, X. Removal of arsenic and cadmium with sequential soil washing techniques using Na 2 EDTA, oxalic and phosphoric acid: Optimization conditions, removal effectiveness and ecological risks. Chemosphere 2016, 156, 252-261. [CrossRef] [PubMed]

26. Gao, L.; Li, C.; Zhang, J.; Du, X.; Li, S.; Zeng, J.; Yi, Y.; Zeng, G. Simultaneous removal of NO and Hg0 from simulated flue gas over $\mathrm{CoOx}-\mathrm{CeO} 2$ loaded biomass activated carbon derived from maize straw at low temperatures. Chem. Eng. J. 2018, 342, 339-349. [CrossRef]

27. Huang, B.; Li, Z.; Huang, J.; Guo, L.; Nie, X.; Wang, Y.; Zhang, Y.; Zeng, G. Adsorption characteristics of Cu and $\mathrm{Zn}$ onto various size fractions of aggregates from red paddy soil. J. Hazard. Mater. 2014, 264, 176-183. [CrossRef] [PubMed]

28. Zhang, Q.; Li, Z.; Huang, B.; Luo, N.; Long, L.; Huang, M.; Zhai, X.; Zeng, G. Effect of land use pattern change from paddy soil to vegetable soil on the adsorption-desorption of cadmium by soil aggregates. Environ. Sci. Pollut. Res. 2016, 24, 2734-2743. [CrossRef] [PubMed]

29. Bao, S.D. Agricultural chemical analysis of soil. Chin. Agric. Press 2000, 6, 154-159.

30. Ball, D.F. Loss-on-ignition as an estimate of organic matter and organic carbon in non-calcareous soils. J. Soil Sci. 1964, 15, 84-92. [CrossRef]

31. Li, Z.-W.; Huang, B.; Huang, J.-Q.; Chen, G.; Xiong, W.-P.; Nie, X.-D.; Ma, W.-M.; Zeng, G.-M. Influence of different phosphates on adsorption and leaching of $\mathrm{Cu}$ and $\mathrm{Zn}$ in red soil. Trans. Nonferrous Met. Soc. China 2016, 26, 536-543. [CrossRef] 
32. Zhai, X.; Li, Z.; Huang, B.; Luo, N.; Huang, M.; Zhang, Q.; Zeng, G. Remediation of multiple heavy metal-contaminated soil through the combination of soil washing and in situ immobilization. J. Total. Environ. 2018, 635, 92-99. [CrossRef] [PubMed]

33. Rahman, M.T.; Kameda, T.; Kumagai, S.; Yoshioka, T. Effectiveness of Mg-Al-layered double hydroxide for heavy metal removal from mine wastewater and sludge volume reduction. Int. J. Environ. Sci. Technol. 2018, 15, 263-272. [CrossRef]

34. Li, X.; Wang, G.Z.; Li, W.G.; Ping, W. Pyrolysis Characteristics and Kinetics of the Preparation Process of Sludge-Based Activated Carbon by ZnCl2 Activation Method. J. Harbin Inst. Technol. 2013, 20, $29-36$.

35. Barrow, N. Reaction of Anions and Cations with Variable-Charge Soils. Adv. Agron. 1986, 38, $183-230$. [CrossRef]

36. Chen, M.; Gong, D. Discrimination of breast tumors in ultrasonic images using an ensemble classifier based on TensorFlow framework with feature selection. J. Investig. Med. 2019, 67 (Suppl. S1), A3.

37. Xu, X.; Cao, X.; Zhao, L.; Wang, H.; Yu, H.; Gao, B. Removal of Cu, Zn, and Cd from aqueous solutions by the dairy manure-derived BC. Environ. Sci. Pollut. Res. 2013, 20, 358-368. [CrossRef]

38. Hossain, M.K.; Strezov, V.; Chan, K.Y.; Ziolkowski, A.; Nelson, P.F. Influence of pyrolysis temperature on production and nutrient properties of wastewater sludge BC. J. Environ. Manag. 2011, 92, 223-228. [CrossRef]

39. Qiu, Y.; Cheng, H.; Xu, C.; Sheng, G.D. Surface characteristics of crop-residue-derived black carbon and lead(II) adsorption. Water Res. 2008, 42, 567-574. [CrossRef]

40. Chen, X.; Chen, G.; Chen, L.; Chen, Y.; Lehmann, J.; McBride, M.B.; Hay, A.G. Adsorption of copper and zinc by BCs produced from pyrolysis of hardwood and corn straw in aqueous solution. Bioresour. Technol. 2011, 102, 8877-8884. [CrossRef]

41. Liu, Z.; Zhang, F.-S. Removal of lead from water using BCs prepared from hydrothermal liquefaction of biomass. J. Hazard. Mater. 2009, 167, 933-939. [CrossRef] [PubMed]

42. Mohan, D.; Pittman, C.U.; Bricka, M.; Smith, F.; Yancey, B.; Mohammad, J.; Steele, P.H.; Alexandre-Franco, M.; Gómez-Serrano, V.; Gong, H.; et al. Sorption of arsenic, cadmium, and lead by chars produced from fast pyrolysis of wood and bark during bio-oil production. J. Colloid Interface Sci. 2007, 310, 57-73. [CrossRef] [PubMed]

43. Martins, R.J.; Pardo, R.; Boaventura, R.A.R. Cadmium(II) and zinc(II) adsorption by the aquatic moss Fontinalis antipyretica: Effect of temperature, $\mathrm{pH}$ and water hardness. Water Res. 2004, 38, 693-699. [CrossRef]

44. Song, Z.; Lian, F.; Yu, Z.; Zhu, L.; Xing, B.; Qiu, W. Synthesis and characterization of a novel MnOx-loaded biochar and its adsorption properties for $\mathrm{Cu} 2+$ in aqueous solution. Chem. Eng. J. 2014, 242, 36-42. [CrossRef]

45. Usman, A.R. The relative adsorption selectivities of $\mathrm{Pb}, \mathrm{Cu}, \mathrm{Zn}, \mathrm{Cd}$ and $\mathrm{Ni}$ by soils developed on shale in New Valley, Egypt. Geoderma 2008, 144, 334-343. [CrossRef]

46. GB18918-2002. Discharge standard of pollutants for municipal wastewater treatment plant. Stand. Press China 2003, 7, 1 .

47. Kadirvelu, K.; Namasivayam, C. Agricutural By-Product as Metal Adsorbent: Sorption of Lead(II) from Aqueous Solution onto Coirpith Carbon. Environ. Technol. 2000, 21, 1091-1097. [CrossRef]

48. Murthy, Z.; Chaudhari, L.B. Separation of binary heavy metals from aqueous solutions by nanofiltration and characterization of the membrane using Spiegler-Kedem model. Chem. Eng. J. 2009, 150, 181-187. [CrossRef]

49. Rezakazemi, M.; Ghafarinazari, A.; Shirazian, S.; Khoshsima, A. Numerical modeling and optimization of wastewater treatment using porous polymeric membranes. Polym. Eng. Sci. 2012, 53, 1272-1278. [CrossRef]

50. Ling, L.L.; Liu, W.J.; Zhang, S.; Jiang, H. Magnesium Oxide Embedded Nitrogen Self-Doped BC Composites: Fast and High-Efficiency Adsorption of Heavy Metals in an Aqueous Solution. Environ. Sci. Technol. 2017, 51, 10081-10089. [CrossRef]

51. Chen, Y.; Geng, Z.J.; Yang, S.S.; Sun, C.Y. Kinetics and thermodynamics for Cu2+ adsorption by modified corn straw. Chin. J. Environ. Eng. 2013, 7, 523-529.

52. Xu, R.C.; Pang, Y. Adsorption characteristics of rice husk BC on Iow-concentration Pb(II) fromwater. Ind. Water Treat. 2020, 40, 35-38.

53. Abdel-Halim, S.; Shehata, A.; El-Shahat, M.F. Removal of lead ions from industrial waste water by different types of natural materials. Water Res. 2003, 37, 1678-1683. [CrossRef] 
54. Marshall, W.E.; Johns, M.M. Agricultural by-products as metal adsorbents: Sorption properties and resistance to mechanical abrasion. J. Chem. Technol. Biotechnol. Biotechnol. 2010, 66, 192-198. [CrossRef]

55. Chen, C.; Cheng, T.; Zhang, X.; Wu, R.; Wang, Q. Synthesis of an efficient Pb adsorption nano-crystal under strong alkali hydrothermal environment using a gemini surfactant as directing agent. J. Chem. Soc. Pak. 2019, 41, 1034-1038.

C 2020 by the authors. Licensee MDPI, Basel, Switzerland. This article is an open access article distributed under the terms and conditions of the Creative Commons Attribution (CC BY) license (http://creativecommons.org/licenses/by/4.0/). 